\title{
Seedling survival in a northern temperate forest understory is increased by elevated atmospheric carbon dioxide and atmospheric nitrogen deposition
}

\author{
LESLEY T. SEFCIK, DONALD R. ZAK and DAVID S. ELLSWORTH \\ School of Natural Resources and Environment, University of Michigan, 440 Church Street, Ann Arbor, MI 48109-1041, USA
}

\begin{abstract}
We tested the main and interactive effects of elevated carbon dioxide concentration $\left(\left[\mathrm{CO}_{2}\right]\right)$, nitrogen $(\mathrm{N})$, and light availability on leaf photosynthesis, and plant growth and survival in understory seedlings grown in an $\mathrm{N}$-limited northern hardwood forest. For two growing seasons, we exposed six species of tree seedlings (Betula papyrifera, Populus tremuloides, Acer saccharum, Fagus grandifolia, Pinus strobus, and Prunus serotina) to a factorial combination of atmospheric $\mathrm{CO}_{2}$ (ambient, and elevated $\mathrm{CO}_{2}$ at $658 \mu \mathrm{mol} \mathrm{CO} \mathrm{Col}^{-1}$ ) and $\mathrm{N}$ deposition (ambient and ambient $+30 \mathrm{~kg} \mathrm{Nha}^{-1} \mathrm{yr}^{-1}$ ) in open-top chambers placed in an understory light gradient. Elevated $\mathrm{CO}_{2}$ exposure significantly increased apparent quantum efficiency of electron transport by $41 \%$ $(P<0.0001)$, light-limited photosynthesis by $47 \%(P<0.0001)$, and light-saturated photosynthesis by $60 \%(P<0.003)$ compared with seedlings grown in ambient $\left[\mathrm{CO}_{2}\right]$. Experimental $\mathbf{N}$ deposition significantly increased light-limited photosynthesis as light availability increased $(P<0.037)$. Species differed in the magnitude of light-saturated photosynthetic response to elevated $\mathrm{N}$ and light treatments $(P<0.016)$. Elevated $\mathrm{CO}_{2}$ exposure and high $\mathrm{N}$ availability did not affect seedling growth; however, growth increased slightly with light availability $\left(R^{2}=0.26, P<0.0001\right)$. Experimental $\mathrm{N}$ deposition significantly increased average survival of all species by $48 \%(P<0.012)$. However, seedling survival was greatest $(85 \%)$ under conditions of both high $\left[\mathrm{CO}_{2}\right]$ and $\mathrm{N}$ deposition $(P<0.009)$. Path analysis determined that the greatest predictor for seedling survival in the understory was total biomass $\left(R^{2}=0.39, P<0.001\right)$, and that carboxylation capacity $\left(V_{\text {cmax }}\right)$ was a better predictor for seedling growth and survival than maximum photosynthetic rate $\left(A_{\max }\right)$. Our results suggest that increasing $\left[\mathrm{CO}_{2}\right]$ and $\mathrm{N}$ deposition from fossil fuel combustion could alter understory tree species recruitment dynamics through changes in seedling survival, and this has the potential to alter future forest species composition.
\end{abstract}

Keywords: elevated $\mathrm{CO}_{2}$, growth, light-limitation, $\mathrm{N}$-limitation, nitrogen, northern hardwood species, path analysis, photosynthesis, shade tolerance, survival

Received 14 June 2006 and accepted 21 August 2006

\section{Introduction}

By producing carbon dioxide $\left(\mathrm{CO}_{2}\right)$ and reactive nitrogen $(\mathrm{N})$ compounds from fossil fuel combustion, human activity has significantly altered atmospheric composition in ways that will strongly affect biospheric functioning (Vitousek et al., 1997). Humans are annually

Correspondence: Lesley Sefcik, tel. + 734647 8012, fax + 734936 2195, e-mail: ltsefcik@umich.edu increasing atmospheric $\left[\mathrm{CO}_{2}\right]$ by $2 \mu \mathrm{mol} \mathrm{mol}^{-1}$, a rate that has changed the concentration by $50 \mu \mathrm{mol} \mathrm{mol}^{-1}$ in the last 30 years (IPCC, 2001). In addition, atmospheric $\mathrm{N}$ deposition due to fossil fuel combustion has globally increased from $1 \mathrm{Tg} \mathrm{Nyr}^{-1}$ in 1860 to $25 \mathrm{Tg} \mathrm{Nyr}^{-1}$ in 2000 (Galloway et al., 2003), which is altering the availability of this limiting nutrient in many terrestrial ecosystems (Aber et al., 2003). Because atmospheric $\left[\mathrm{CO}_{2}\right]$ and $\mathrm{N}$ deposition each have the potential to alter plant physiology, these factors could affect the future composition of northern forest ecosystems by affecting 
the growth, survival, and recruitment dynamics of forest tree species (Hättenschwiler \& Körner, 2000).

Elevated $\mathrm{CO}_{2}$ exposure generally causes an increase in growth and photosynthesis in $\mathrm{C}_{3}$ plants (Bazzaz et al., 1990; Curtis \& Wang, 1998). Plants grown under elevated $\left[\mathrm{CO}_{2}\right]$ have also shown an increase in survival (Rochefort \& Bazzaz, 1992). However, the magnitude of the physiological response of understory tree species to elevated $\left[\mathrm{CO}_{2}\right]$ largely depends on the availability of other essential plant resources, such as light and mineral nutrients (Bazzaz et al., 1990; Bazzaz \& Fajer, 1992; Bazzaz \& Miao, 1993; Sholtis et al., 2004). For example, long-term gains due to $\mathrm{CO}_{2}$ enrichment may be offset by downregulation of photosynthetic rate over time (Hättenschwiler et al., 1997; Rey \& Jarvis, 1998; Greenep et al., 2003). These photosynthetic adjustments to $\mathrm{CO}_{2}$ enrichment are usually more distinct when soil $\mathrm{N}$ availability is low, and this may be due to reduced growth sinks for $\mathrm{C}$ associated with $\mathrm{N}$-limitation (Wolfe et al., 1998; Laitinen et al., 2000; Oren et al., 2001; Reich et al., 2006). It is unclear whether photosynthetic downregulation is alleviated with increased $\mathrm{N}$ availability, for example, from increased $\mathrm{N}$ deposition due to fossil fuel combustion. It is also unclear how changes in photosynthesis might alter growth and survival responses of understory seedlings.

Soil $\mathrm{N}$ availability is one of the main factors limiting plant growth in temperate forests throughout North America (Aber et al., 1989, 2001; Hungate et al., 2003). On average, increased $\mathrm{N}$ availability results in increased photosynthesis and growth in northern hardwood trees (Latham, 1992). $\mathrm{N}$ is a key component of photosynthesis because chlorophyll concentration, Rubisco (ribulose-15-biphosphate carboxylase), and plant growth all increase with greater N availability (Field \& Mooney, 1983; Kutik et al., 1995; Bondada \& Syvertsen, 2003). However, some studies have demonstrated a mixed relationship between survival and $\mathrm{N}$ availability in low light (Catovsky \& Bazzaz, 2002). In deep shade, shade tolerant species tend to increase survival in response to high $\mathrm{N}$ availability, whereas shade intolerant species exhibit $\mathrm{N}$-induced declines in survival (Catovsky \& Bazzaz, 2002). When light is increased, survival has been shown to increase with greater $\mathrm{N}$ availability (Walters \& Reich, 2000). Increases in atmospheric $\mathrm{N}$ deposition can affect the amount of $\mathrm{N}$ available to plants and this has the potential to influence seedling performance and survival in the understory (Catovsky \& Bazzaz, 2002). Changes in N deposition may also alter regeneration patterns in forest ecosystems through changes in tree and microbial physiology (Lovett \& Lindberg, 1986, 1993; Magill et al., 2004).

Few studies have investigated the interactive effects of multiple environmental factors such as
$\left[\mathrm{CO}_{2}\right]$, mineral nutrients, and dynamic light environment, on understory seedling physiology, growth, and survival (Bazzaz \& Miao, 1993; Naumburg \& Ellsworth, 2000; Kerstiens, 2001). If changes in atmospheric $\left[\mathrm{CO}_{2}\right]$ and $\mathrm{N}$ deposition affect the physiological responses and survival of understory seedlings, this may alter forest composition because seedling survival largely determines future community composition (Rossell et al., 2005). Changes in physiology, growth, and survival may increase the competitive ability of some species relative to others (Bazzaz et al., 1990). These changes in competitive ability could then modify forest species composition, and this may feed back to alter the future functioning of these ecosystems in the face of environmental stress (Hättenschwiler \& Körner, 2000).

We examined the interactive effects of atmospheric $\left[\mathrm{CO}_{2}\right]$ and $\mathrm{N}$ deposition on the physiological responses of seedlings of six tree species growing in an understory light gradient in an N-limited, northern hardwood forest to better understand how climate change might alter future forest composition and function. We measured the physiological responses of Betula papyrifera, Populus tremuloides, Acer saccharum, Fagus grandifolia, Pinus strobus, and Prunus serotina seedlings growing in two levels of soil $\mathrm{N}$ availability and two concentrations of atmospheric $\mathrm{CO}_{2}$ to determine if different levels of understory shade modified these responses. We hypothesized that:

1. Experimental $\mathrm{N}$ deposition would increase leaf $N_{\text {area }}$ photosynthesis, growth, and survival of N-limited understory seedlings by increasing $\mathrm{N}$ availability. This stimulation would be greatest in higher light.

2. $\mathrm{CO}_{2}$ enrichment would increase photosynthesis, growth, and survival for understory seedlings by improving plant carbon balance. This stimulation would be greatest in higher light combined with high $\mathrm{N}$ availability.

3. Downregulation of photosynthesis would occur for seedlings grown in elevated $\left[\mathrm{CO}_{2}\right]$ and low $\mathrm{N}$ availability due to N-limitation in the nutrient poor soil of our study site (Sefcik et al., 2006).

4. Greater light-saturated photosynthesis and carboxylation capacity resulting from greater atmospheric resources (elevated $\left[\mathrm{CO}_{2}\right]$ and $\mathrm{N}$ ) would alleviate photosynthetic downregulation, and increase growth and rates of survival for seedlings in this N-limited understory environment.

\section{Materials and methods}

Light and atmospheric $\mathrm{CO}_{2}$

To study the interaction between $\left[\mathrm{CO}_{2}\right], \mathrm{N}$, and light, on the physiology of northern hardwood tree seedlings, 
we surveyed the light environment of a $2500 \mathrm{~m}^{2}$ forest stand to place $\mathrm{CO}_{2}$ chambers within microsites of varying light conditions (see Sefcik et al., 2006). The northern hardwood forest stand was located in a 90-year-old forest dominated by P. tremuloides at the University of Michigan Biological Station in northern Lower Michigan $\left(45^{\circ} 34^{\prime} \mathrm{N}, 84^{\circ} 40^{\prime} \mathrm{W}\right)$. The site was described in Sefcik et al. (2006). Understory irradiance was quantified before establishment of the $\mathrm{CO}_{2}$ experiment in the summer of 2001 on 5 different days (11:00 and 15:00 hours) using a line quantum sensor (Ceptometer, Decagon Devices, Pullman, WA, USA). On overcast days, diffuse light in the understory was compared with that in a nearby clearing. Because diffuse light photon flux density (PFD) at the understory measurement location is an accurate estimate of mean daily PFD, diffuse light was used to guide placement of experimental chambers (Parent \& Messier, 1996). Mean PFD under clear-sky conditions was also quantified at each location using the same method as the diffuse sky measurements.

Twenty light microsites were randomly selected from a pool of forty prospective light locations for the shade treatments. The experiment was conducted in an understory light gradient with irradiance ranging from approximately $2 \%$ to $8 \%$ of full sunlight. The average diffuse light PFD ranged from $6.5 \pm 0.2$ to $14.2 \pm$ $0.2 \mu \mathrm{mol} \mathrm{m}^{-2} \mathrm{~s}^{-1}$ (Sefcik et al., 2006) characterizing levels in the understory of typical northern hardwood forests (Hättenschwiler \& Körner, 2000) and was selected to challenge the survival of shade intolerant species (Latham, 1992; Walters et al., 1993b). Clear-sky measurements of understory PFD for sunny days with mid-day PFD of $1700-1800 \mu \mathrm{mol} \mathrm{m}^{-2} \mathrm{~s}^{-1}$ in a nearby clearing, determined that the mean light levels among the chamber locations in the understory ranged from $62 \pm 20$ to $224 \pm 65 \mu \mathrm{mol} \mathrm{m}^{-2} \mathrm{~s}^{-1}$ (Sefcik et al., 2006).

Two open-top chambers were then positioned on the forest floor within each of the 20 light microsites. Within each light microsite $(N=20)$, open-top chambers $(N=2$ per light microsite, $N=40$ ) were randomly assigned to treatments of ambient or elevated $\left[\mathrm{CO}_{2}\right]$. A blower system was used to apply elevated or ambient $\mathrm{CO}_{2}$ into open-top chambers $\left(0.64 \mathrm{~m}^{2} \times 1.5 \mathrm{~m}\right.$ high; Mikan et al., 2000). For the elevated $\mathrm{CO}_{2}$ treatment, atmospheric $\left[\mathrm{CO}_{2}\right]$ was increased by supplying $100 \% \mathrm{CO}_{2}$ into an input blower via manual flow meters (Curtis et al., 2000). $\mathrm{CO}_{2}$ exposure began 6 June 2002 and was continuous until leaf drop ca. 20 September 2002. In the second year of the experiment, $\mathrm{CO}_{2}$ exposure began 2 May and continued until 3 October 2003. Using an infrared gas analyzer, $\left[\mathrm{CO}_{2}\right]$ was measured continuously in every elevated $\mathrm{CO}_{2}$ chamber and two randomly selected ambient $\mathrm{CO}_{2}$ chambers (Curtis et al., 2000). Seedlings in the control treatment were exposed to ambient air for $24 \mathrm{~h}$ daily with average daytime (07:00-19:00 hours) $\left[\mathrm{CO}_{2}\right]$ of $383 \pm 13 \mu \mathrm{molCO}_{2} \mathrm{~mol}^{-1}$ (mean of daily averages across all chambers $\pm \mathrm{SE}$ ). Seedlings grown in elevated $\left[\mathrm{CO}_{2}\right]$ were supplemented with $\mathrm{CO}_{2}$ for $24 \mathrm{~h}$ daily during the experiment with average daytime (07:00-19:00 hours) $\left[\mathrm{CO}_{2}\right]$ of $658 \pm$ $10 \mu \mathrm{molCO}_{2} \mathrm{~mol}^{-1}$. Internal chamber temperatures were approximately $1{ }^{\circ} \mathrm{C}$ warmer than ambient air; however, this caused no noticeable changes in phenology. Seedlings were exposed to treatment combinations for at least 1 month before any physiological measurements were conducted.

\section{Plant material and $N$}

Sixteen bare-rooted, northern hardwood tree seedlings were planted in the surface mineral soil in each chamber. Three individuals each of B. papyrifera, $P$. tremuloides, A. saccharum, F. grandifolia, P. strobus and one individual of $P$. serotina, were randomly planted in a $16 \mathrm{~cm} \times 16 \mathrm{~cm}$ grid within each chamber. These species represent a range of shade-intolerant (B. papyrifera, $P$. tremuloides, $P$. serotina) and shade-tolerant tree species (A. saccharum, F. grandifolia, and P. strobus; Baker, 1949) common to northern hardwood forests. First-year seedlings of $F$. grandifolia were acquired from a natural population in a nearby forest. P. tremuloides were grown from seed under greenhouse conditions. One-year-old nursery stock was used for all other species.

In each chamber location, soil properties were studied to determine whether $\mathrm{CO}_{2}$ and light treatments were confounded with soil nutrient availability. Soils were analyzed for texture, $\mathrm{pH}$, potential net mineralization, and net nitrification. Soil in the experimental forest site was a nutrient and organic matter poor, sandy spodosol $\left(\mathrm{pH}=4.3 ;\right.$ organic $\left.\mathrm{C}=2352 \pm 90 \mathrm{~g} \mathrm{C} \mathrm{m}^{-2}\right)$. Over a 4-week laboratory incubation, net nitrification was $0.02 \pm 0.007 \mathrm{~g} \mathrm{~N} \mathrm{~m}^{-2}$ soil and net $\mathrm{N}$ mineralization was $0.1 \pm 0.01 \mathrm{~g} \mathrm{~N} \mathrm{~m}^{-2}$ soil, comparable with published rates for the region (Zak et al., 1993). For complete site characteristics see Sefcik et al. (2006). Soil nutrient availability was not confounded with any treatment.

In the second year of the study, half of the light microsites $(N=10)$ were randomly selected for $\mathrm{N}$ addition. $\mathrm{N}$-treatment levels were ambient $\mathrm{N}$ deposition and ambient $+30 \mathrm{~kg} \mathrm{Nha}^{-1} \mathrm{yr}^{-1}$ in the form of sodium nitrate (Pregitzer et al., 2004). The $+30 \mathrm{~kg} \mathrm{~N} \mathrm{ha}^{-1} \mathrm{yr}^{-1}$ treatment is equivalent to current rates of deposition in the northeast United States and Europe (Galloway et al., 2003). The nitrate treatment was applied on five occasions from June to early August in the second growing season of the study. Sodium nitrate was dissolved in de-ionized water and sprayed as a solution onto the soil surface for each chamber location using a backpack 
chemical sprayer. $\mathrm{N}$ was delivered in $1 \mathrm{~L}$ of solution and an equivalent amount of de-ionized water was applied to the control treatments using a separate backpack sprayer.

\section{Photosynthesis measurements}

We examined the influence of $\mathrm{CO}_{2}$ exposure, $\mathrm{N}$, and light availability on leaf net photosynthesis using the Li-Cor 6400 gas exchange system (Li-Cor, Lincoln, NE). The measurements and analyses were conducted as described previously (Sefcik et al., 2006). In brief, photosynthetic light response curves for each species were developed using controlled $\mathrm{CO}_{2}$ and light levels. Plants were sampled randomly within a chamber and among treatments to minimize the possibility of diurnal patterns confounding treatment effects. Healthy, fully expanded, intact leaves in the top of the crown were selected for measurements of leaves beginning with brief $(8-10 \mathrm{~min})$ acclimation to saturating irradiance.

In the second growing season of the study, the lightsaturated photosynthetic response to varying intercellular $\left[\mathrm{CO}_{2}\right]\left(A-C_{\mathrm{i}}\right.$ curves) was measured for one plant of B. papyrifera, P. serotina, A. saccharum, and F. grandifolia from $n=5$ seedlings per $\mathrm{CO}_{2}, \mathrm{~N}$, and light treatment per species (totaling $N=160$ seedlings). Measurements were taken between 11:00 and 15:00 hours in August to ensure induction by light (Naumburg \& Ellsworth, 2000). Response curves to controlled $\left[\mathrm{CO}_{2}\right]$ steps were developed using a constant saturating PFD of $1000 \mu \mathrm{mol} \mathrm{m}^{-2} \mathrm{~s}^{-1}$ as described previously (Sefcik et al., 2006). The slope of the first three to four data points below $260 \mu \mathrm{mol} \mathrm{CO} \mathrm{mol}^{-1}$ were used to calculate the maximum carboxylation rate $\left(V_{\text {cmax }} ;\right.$ Farquhar et al., 1980) fitted as described in Ellsworth et al. (2004). Leaves were collected following leaf gas-exchange measurements and dried at $70^{\circ} \mathrm{C}$ to a constant mass; total $\mathrm{N}$ in these samples was determined using a Carlo Erba NA 1500 (Carlo Erba, Milan, Italy). A $2.2 \mathrm{~cm}^{2}$ circular disk was removed from each leaf to determine mass per unit leaf area to calculate $N_{\text {area }}$.

Light response curves at growth $\left[\mathrm{CO}_{2}\right]$ were also conducted in the second year of the study. One plant of B. papyrifera, P. serotina, A. saccharum, and F. grandifolia from each of the 40 experimental chambers was measured $(N=5$ per treatment per species, totaling $N=160$ ). In addition, to facilitate analysis of downregulation of photosynthesis, light response curves at elevated $\left[\mathrm{CO}_{2}\right]$ were generated for plants grown in ambient $\left[\mathrm{CO}_{2}\right]$ ( $n=5$ per treatment per species, totaling $N=80$ ). Photosynthetic responses were measured in mid-summer by changing light stepwise across nine levels (1000, 500, 300, 200, 130, 100, 50, 20, and
$0 \mu \mathrm{mol} \mathrm{m}{ }^{-2} \mathrm{~s}^{-1}$ ) while sustaining a steady ambient or elevated $\left[\mathrm{CO}_{2}\right]$. A rectangular hyperbolic model was used to extrapolate the light compensation point $\left(\mu \mathrm{mol} \mathrm{m}{ }^{-2} \mathrm{~s}^{-1}\right.$; Hanson et al., 1987). We used four data points $\left(0,20,50\right.$, and $\left.100 \mu \mathrm{mol} \mathrm{m}^{-2} \mathrm{~s}^{-1}\right)$ in fitting apparent quantum efficiency $\left[\mathrm{molCO}_{2} \mathrm{~mol}^{-1}\right.$ incident photon (Singsaas et al., 2001)] and fits to the initial slope had $r^{2}$ greater than 0.83 .

\section{Measurements of plant size and survival}

Plant growth was measured as the increment in plant dimensions and/or biomass over time to determine how $\left[\mathrm{CO}_{2}\right], \mathrm{N}$, light availability, and their interaction, affected growth for each species. Plant height and basal diameter were measured at the time of planting in early May 2001. Plant height and basal diameter were assessed three times during each growing season thereafter. Plant height was measured from the soil-stem surface to the tip of the apical bud and the diameter was assessed at the soil surface. In September of 2003, all remaining live plants were measured for height and basal diameter and then harvested. Height growth was determined by subtracting initial height from final height. All plants were separated into roots, stems, and leaves. For each plant, leaf punches were made in two randomly selected leaves to assess leaf mass per unit area. Plants were dried to a constant mass in a $70^{\circ} \mathrm{C}$ oven and then weighed. Aboveground, belowground, and total biomass was determined using initial plant height as a covariate to account for any differences in initial plant size (Bazzaz et al., 1990). Seedling survival was also assessed at the end of each growing season during the experiment.

\section{Statistical analysis}

In our experiment, $\mathrm{CO}_{2}$ treatments $(383 \pm 13$ and $658 \pm 10 \mu \mathrm{mol} \mathrm{CO}_{2} \mathrm{~mol}^{-1}$ ) were crossed with light (see Sefcik et al., 2006) and $\mathrm{N}$ treatments (this study). A separate linear-mixed ANCOVA model was fit to the data for each dependent variable of interest, with $\left[\mathrm{CO}_{2}\right], \mathrm{N}$, and species as fixed factors, and light tested in the model as a covariate. The fraction of the variance in the measurements due to random chamber effects was estimated using random intercepts in the linear-mixed model (Gueorguieva \& Krystal, 2004). If the random factor (chamber) effects were not significant, this factor was dropped and a univariate ANCOVA model was used. For photosynthetic and growth parameters, a univariate ANCOVA model was used, and for all growth parameters, initial plant height was included as a covariate in the model. For growth and survival, all three- and four-way interaction terms were not significant; therefore, only 
main effects and two-way interactions were tested to increase statistical power. For the analysis of survival, seedlings of the same species in the same chamber were aggregated to create a proportional survival estimate for each species within a chamber.

Path analyses were used to examine the interactive effects of $\left[\mathrm{CO}_{2}\right], \mathrm{N}$, and light availability on photosynthetic parameters [maximum carboxylation capacity $\left(V_{\text {cmax }}\right)$, and maximum photosynthesis $\left.\left(A_{\max }\right)\right]$, total biomass and survival. Path analyses did not include $P$. tremuloides or $P$. strobus because complete photosynthesis, growth, and survival data were required for the analysis, and we did not have a complete data set for these species. Path analyses could not be conducted for each species separately, or within shade tolerance groups, due to small sample sizes relative to the number of treatments, and our analyses, therefore, combined information for all species into one model. We recognize that paths may vary for different species. The values associated with each path are standardized total regression coefficients and indicate the number of standard deviations of change in the dependent variable expected from a unit change in the independent variable (Mitchell, 2001; Sterck \& Bongers, 2001; Baraloto et al., 2005). Structured-equation modeling or path analysis is highly sensitive to the choice of variables and their interactions/pathways (Grace \& Pugesek, 1998). Maximum carboxylation capacity was selected as a predictor and response variable to test, because it can provide information on the amount of active Rubisco enzyme in leaves, which is critical to growth and survival in understory environments (Manter et al., 2005). Light-saturated maximum photosynthetic rate $\left(A_{\max }\right)$ was also selected as a key predictor and response variable because it is one of the most common physiological metrics assessed in plant ecology, and it is of primary importance to plant carbon gain and therefore assumed to be a major component that determines growth (Reich et al., 1998). The significance of the standardized total (direct and indirect) effect is shown on the arrows connecting parameters (e.g. see Fig. 4).

In each of the statistical analyses, the assumptions of normality and constant variance in the random errors were assessed with customary diagnostic tools. Standard transformations were used if the errors were not normally distributed. All univariate and linear-mixed model ANCOVA statistical analyses were completed with SPSS v.13.0 (SPSS, Chicago, IL, USA). Effects were considered significant when $P<0.05$ in ANCOVA. Path analyses were completed with Amos v.5.0.1 software (SmallWaters Corp., Chicago, IL, USA). Effects were considered significant when $P<0.1$ for all path analyses.

\section{Results}

\section{$N$ per unit leaf area}

Specific leaf area (SLA) and $\mathrm{N}$ per unit leaf area $\left(N_{\text {area }}\right)$ of individual species both displayed a four-way interaction with $\left[\mathrm{CO}_{2}\right], \mathrm{N}$, and light availability, which renders a biologically meaningful interpretation of the data difficult (Table $1, N_{\text {area }} P<0.015$; SLA data not shown). A. saccharum, $F$. grandifolia and $B$. papyrifera exhibited the greatest $N_{\text {area }}$ when grown in elevated $\left[\mathrm{CO}_{2}\right]$, with high $\mathrm{N}$ and light availability. A. saccharum demonstrated mean $N_{\text {area }}$ of $1.30 \pm 0.19 \mathrm{~g} \mathrm{~N} \mathrm{~m}^{-2}$ in elevated $\left[\mathrm{CO}_{2}\right]$ and high light. In the same treatment combination, F. grandifolia had $0.99 \pm 0.06 \mathrm{~g} \mathrm{~N} \mathrm{~m}^{-2}$ and B. papyrifera exhibited $1.23 \pm 0.15 \mathrm{~g} \mathrm{~N} \mathrm{~m}^{-2}$. P. serotina displayed the greatest $N_{\text {area }}$ in ambient $\left[\mathrm{CO}_{2}\right]$ with low $\mathrm{N}$ and low light availability $\left(1.32 \pm 0.12 \mathrm{~g} \mathrm{~N} \mathrm{~m}^{-2}\right)$, contrary to all other species (Table $1, P<0.004$ ). Overall, high $\mathrm{N}$ availability stimulated $N_{\text {area }}$ the most as light increased (Table $1, P<0.026$ ). Plants grown in elevated $\left[\mathrm{CO}_{2}\right]$ and high light also demonstrated significantly greater $N_{\text {area }}\left(0.99 \pm 0.05 \mathrm{~g} \mathrm{~N} \mathrm{~m}^{-2}\right)$ than those grown in ambient $\left[\mathrm{CO}_{2}\right]$ and equivalent light $(0.86 \pm 0.04 \mathrm{~g}$ $\mathrm{N} \mathrm{m}^{-2}$; Table $\left.1, P<0.001\right)$. However, this relationship changed in low light, wherein seedlings grown in elevated $\left[\mathrm{CO}_{2}\right]$ generally had lower $N_{\text {area }}(0.85 \pm 0.05 \mathrm{~g}$ $\left.\mathrm{N} \mathrm{m}^{-2}\right)$ than those grown in ambient $\left[\mathrm{CO}_{2}\right](0.93 \pm$ $0.04 \mathrm{~g} \mathrm{~N} \mathrm{~m}^{-2}$ ). There were significant species main effects on $N_{\text {area }}$ with $P$. serotina exhibiting the greatest $N_{\text {area }}\left(1.12 \pm 0.02 \mathrm{~g} \mathrm{~N} \mathrm{~m}^{-2}\right)$ and $F$. grandifolia the lowest $\left(0.79 \pm 0.03 \mathrm{~g} \mathrm{~N} \mathrm{~m}^{-2}\right.$; Table $\left.1, P<0.0001\right) . \mathrm{CO}_{2}$ treatment also altered $N_{\text {area }}$ with plants grown in elevated $\left[\mathrm{CO}_{2}\right]$ displaying higher $N_{\text {area }}\left(0.93 \pm 0.03 \mathrm{~g} \mathrm{~N} \mathrm{~m}^{-2}\right)$ than those seedlings grown in ambient $\left[\mathrm{CO}_{2}\right]\left(0.89 \pm 0.03 \mathrm{~g} \mathrm{~N} \mathrm{~m}^{-2}\right.$; Table $1, P<0.003)$.

\section{Photosynthesis}

Elevated $\mathrm{CO}_{2}$ exposure significantly increased lightsaturated photosynthesis (measured at $1000 \mu \mathrm{mol}$ photons $\mathrm{m}^{-2} \mathrm{~s}^{-1}$ ), light-limited photosynthesis (measured at $130 \mu \mathrm{mol}$ photons $\mathrm{m}^{-2} \mathrm{~s}^{-1}$ irrespective of growth light environment) and apparent quantum efficiency of electron transport (Table 1). Plants grown in elevated $\left[\mathrm{CO}_{2}\right]$ had $60 \%$ greater light-saturated net photosynthesis $(P<0.003), 47 \%$ greater light-limited photosynthesis $(P<0.0001)$, and $41 \%$ greater apparent quantum efficiency of electron transport $(P<0.001)$ than seedlings grown in ambient $\left[\mathrm{CO}_{2}\right]$. Seedlings grown in elevated $\left[\mathrm{CO}_{2}\right]$ with low $\mathrm{N}$ availability displayed $11 \%$ downregulation of light-saturated photosynthetic capacity (Fig. $1 ; P<0.003$, data not shown in a table). However, for species grown in elevated $\left[\mathrm{CO}_{2}\right]$, high $\mathrm{N}$ 


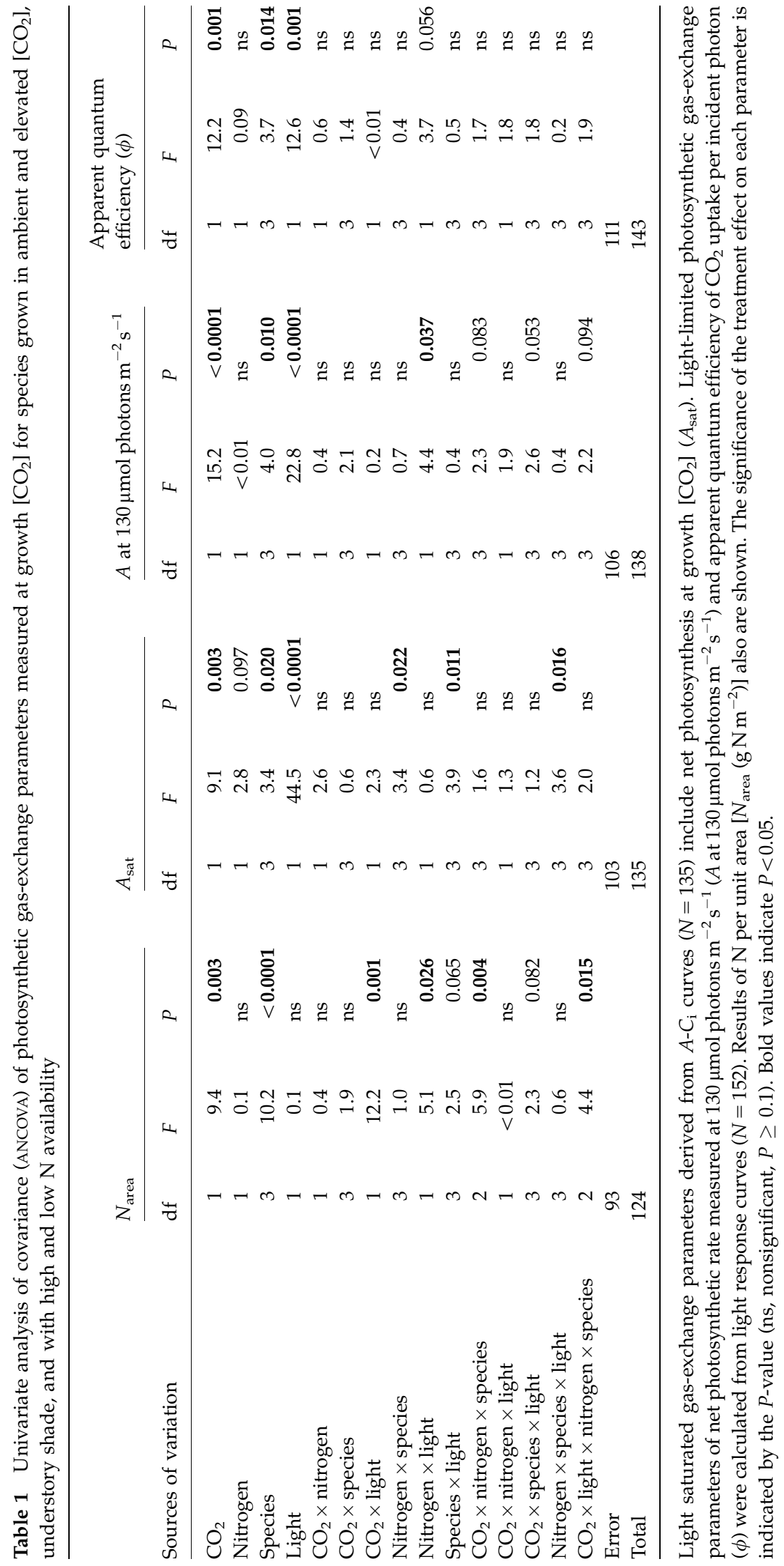


availability alleviated the downregulation response for light-saturated net photosynthetic rate (Fig. 1; Table 2, $P<0.041$ ). High $\mathrm{N}$ availability did not significantly affect $V_{\text {cmax }}$ (Table 2, $P>0.05$ ).

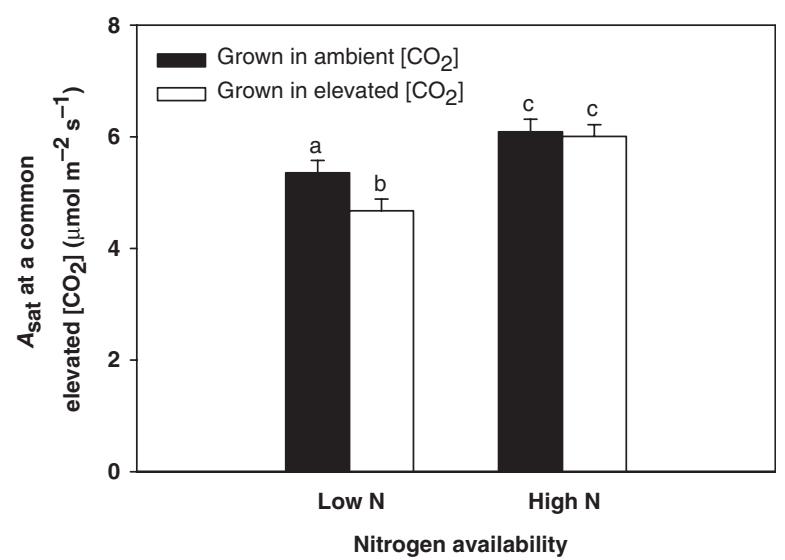

Fig. 1 Light-saturated net photosynthetic rate measured at a common elevated $\left[\mathrm{CO}_{2}\right]$ for plants grown in ambient or elevated $\left[\mathrm{CO}_{2}\right]$ and high and low $\mathrm{N}$ availability. Black bars indicate $A_{\text {sat }}$ for plants grown in ambient $\left[\mathrm{CO}_{2}\right]$ and white bars represent $A_{\text {sat }}$ for plants grown in elevated $\left[\mathrm{CO}_{2}\right]$. Bonferroni multiple comparisons with $P<0.025$ (equivalent to experimental-wise $P<0.05$ ) are shown. Distinct letters denote differences.
Species light-saturated net photosynthesis rate was dependent on light and $\mathrm{N}$ availability in the understory (Table $1, P<0.016$ ). For $A$. saccharum, $B$. papyrifera, and $P$. serotina there was no significant interaction between $\mathrm{N}$ treatment and growth light environment (Fig. 2). However, F. grandifolia exhibited a significant light by $\mathrm{N}$ interaction; when grown with low $\mathrm{N}$ availability, seedlings showed no increase in light-saturated net photosynthesis as light increased, whereas, with high $\mathrm{N}$ availability, an increase in light substantially increased light-saturated net photosynthesis (Fig. 2, $P<0.040$ ). For light-limited photosynthesis, plants displayed a significant light by $\mathrm{N}$ interaction suggesting that seedlings growing with high $\mathrm{N}$ availability significantly increased photosynthesis as light availability increased (Table 1, $P<0.037)$. In contrast, $N$ availability did not significantly influence apparent quantum efficiency of electron transport (Table 1, $P>0.05$ ).

Light-limited photosynthesis differed by species, with shade tolerant species generally displaying lower rates of photosynthesis than more shade intolerant species (Table $1, P<0.010)$. A. saccharum and F. grandifolia displayed light-limited photosynthesis of $2.8 \pm 0.1 \mu \mathrm{mol} \mathrm{m}{ }^{-2} \mathrm{~s}^{-1}$, while B. papyrifera and P. serotina exhibited rates of $3.8 \pm 0.2 \mu \mathrm{mol} \mathrm{m}^{-2} \mathrm{~s}^{-1}$. Apparent quantum efficiency also differed by species as $A$. saccharum and F. grandifolia displayed lower apparent

Table 2 Univariate analysis of covariance (ANCOVA) of photosynthetic gas-exchange parameters for species grown in ambient and elevated $\left[\mathrm{CO}_{2}\right]$, understory shade, and with high and low $\mathrm{N}$ availability

\begin{tabular}{|c|c|c|c|c|c|c|}
\hline \multirow[b]{2}{*}{ Sources of variation } & \multicolumn{3}{|c|}{$A_{\text {sat }}$ at common elevated $\left[\mathrm{CO}_{2}\right]$} & \multicolumn{3}{|c|}{$V_{\text {cmax }}$ at $25^{\circ} \mathrm{C}$} \\
\hline & $\mathrm{df}$ & $F$ & $P$ & $\mathrm{df}$ & $F$ & $P$ \\
\hline $\mathrm{CO}_{2}$ & 1 & 4.5 & 0.035 & 1 & 2.6 & ns \\
\hline Nitrogen & 1 & 0.6 & ns & 1 & 0.8 & ns \\
\hline Species & 3 & 3.9 & 0.011 & 3 & 9.9 & $<0.0001$ \\
\hline Light & 1 & 31.2 & $<0.0001$ & 1 & 34.1 & $<0.0001$ \\
\hline $\mathrm{CO}_{2} \times$ nitrogen & 1 & 4.3 & 0.041 & 1 & 1.7 & ns \\
\hline $\mathrm{CO}_{2} \times$ species & 3 & 0.5 & ns & 3 & 0.3 & ns \\
\hline $\mathrm{CO}_{2} \times$ light & 1 & 2.2 & ns & 1 & 0.4 & ns \\
\hline Nitrogen $\times$ species & 3 & 4.3 & 0.006 & 3 & 2.4 & 0.070 \\
\hline Nitrogen $\times$ light & 1 & 1.7 & ns & 1 & 1.0 & ns \\
\hline Species $\times$ light & 3 & 3.8 & 0.013 & 3 & 2.7 & 0.047 \\
\hline $\mathrm{CO}_{2} \times$ nitrogen $\times$ species & 3 & 1.9 & ns & 3 & 1.3 & ns \\
\hline $\mathrm{CO}_{2} \times$ nitrogen $\times$ light & 1 & 2.5 & ns & 1 & 0.8 & ns \\
\hline $\mathrm{CO}_{2} \times$ species $\times$ light & 3 & 1.0 & ns & 3 & 1.0 & ns \\
\hline Nitrogen $\times$ species $\times$ light & 3 & 5.2 & 0.002 & 3 & 2.6 & 0.059 \\
\hline $\mathrm{CO}_{2} \times$ light $\times$ nitrogen $\times$ species & 3 & 2.3 & 0.084 & 3 & 2.2 & 0.095 \\
\hline Error & 103 & & & 103 & & \\
\hline Total & 135 & & & 135 & & \\
\hline
\end{tabular}

Light-saturated net photosynthetic rate $\left(A_{\text {sat }}\right)$ measured at a common elevated $\left[\mathrm{CO}_{2}\right]$ and carboxylation capacity $\left(V_{\mathrm{cmax}}\right)$ at $25^{\circ} \mathrm{C}$ from model fits, are derived from analysis of $A-C_{\mathrm{i}}$ curves. The significance of the treatment effect on each parameter is indicated by the $P$-value (ns, nonsignificant, $P \geq 0.1$ ). Bold values indicates $P<0.05$. 

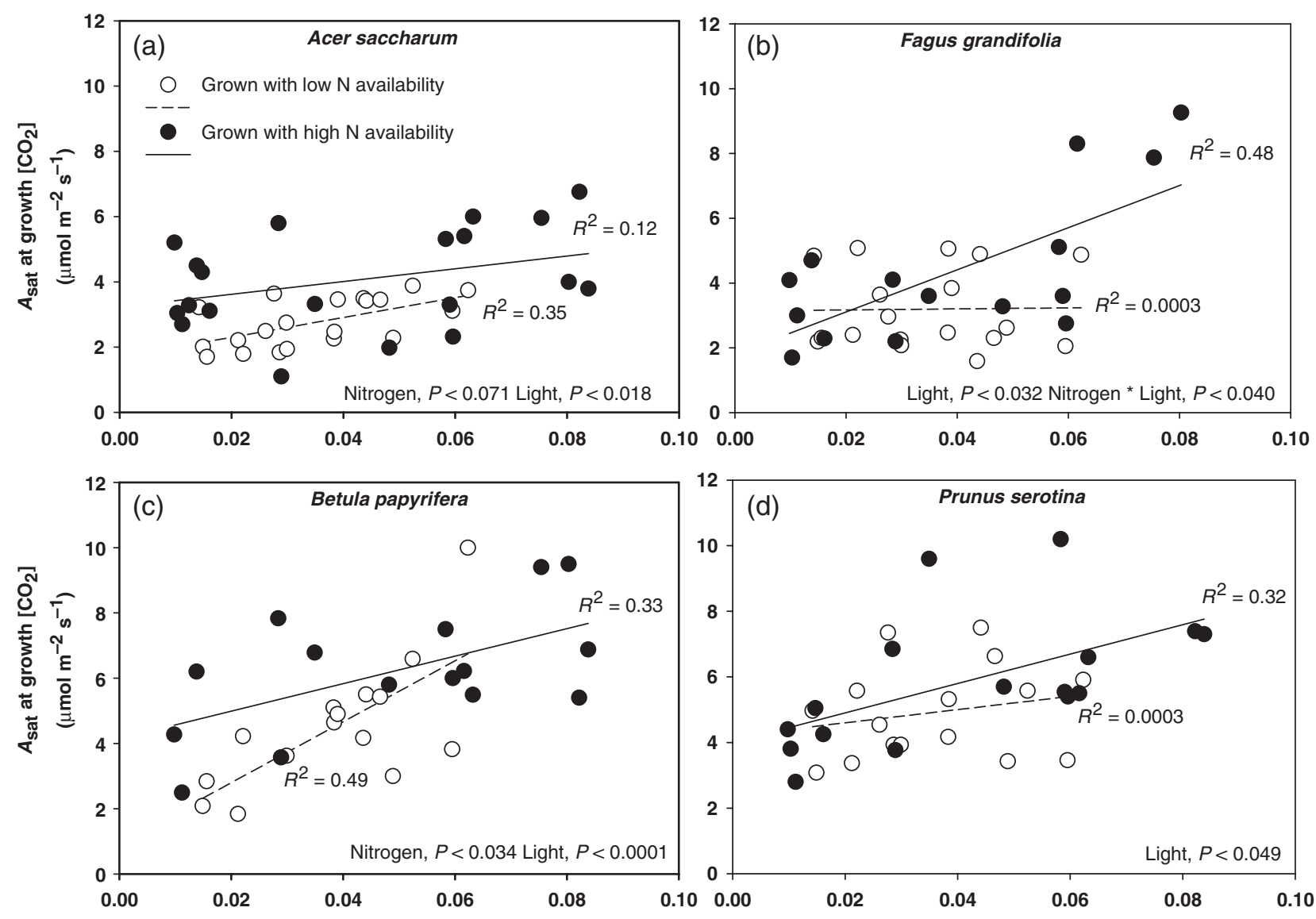

(c)

Betula papyrifera
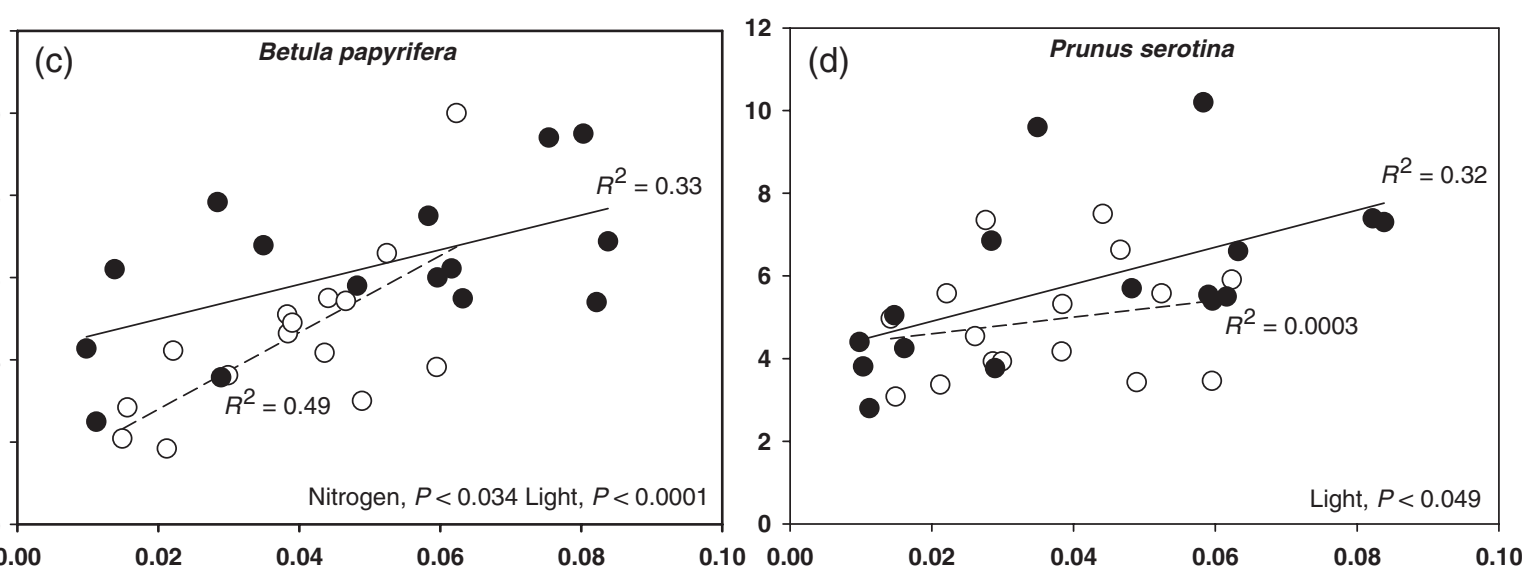

Fig. 2 Light-saturated net photosynthetic rate displayed by species [(a) Acer saccharum, (b) Fagus grandifolia, (c) Betula papyrifera, and (d) Prunus serotina], growth light, and $\mathrm{N}$ treatment is shown. White circles indicate $A_{\text {sat }}$ for plants grown in low $\mathrm{N}$ availability and black circles represent $A_{\text {sat }}$ for plants grown with high $\mathrm{N}$ availability. Within species ANCOvA results testing light, $\mathrm{N}$ and light ${ }^{*} \mathrm{~N}$ interaction are shown at the bottom of each panel. $R^{2}$ values are shown for each regression.

quantum efficiency $\left(0.028 \pm 0.001 \mathrm{molCO}_{2} \mathrm{~mol}^{-1}\right.$ incident photon) than more shade intolerant $B$. papyrifera and P. serotina $\left(0.037 \pm 0.002 \mathrm{~mol} \mathrm{CO}_{2} \mathrm{~mol}^{-1}\right.$ incident photon; Table 1, $P<0.014$ ). Apparent quantum efficiency also increased with light availability (Table 1 , $P<0.001)$.

\section{Growth}

Increases in photosynthesis due to elevated $\mathrm{CO}_{2}$ exposure and high $\mathrm{N}$ availability did not translate into greater aboveground, belowground, total biomass or height growth (Table 3, $P>0.05$ ). However, seedling growth differed by species $(P<0.0001)$ and generally increased with light availability (Table $3, P<0.005$ ). There was a significant light by species interaction for aboveground biomass $(P<0.0001)$ and for height growth (Table 3, $P<0.007$ ). Multiple comparisons tests (data not shown in a table) demonstrated that P. strobus
$\left(R^{2}=0.61, \quad P<0.0001\right), \quad$ A. saccharum $\quad\left(R^{2}=0.28\right.$, $P<0.002)$, B. papyrifera $\left(R^{2}=0.69, P<0.001\right)$, and $F$. grandifolia $\left(R^{2}=0.46, P<0.017\right)$ all displayed small but significant increases in aboveground biomass as light availability increased from approximately $2 \%$ to $8 \%$ of full sunlight. P. tremuloides and P. serotina showed little change in aboveground biomass as light availability increased $(P>0.1)$. Belowground biomass also differed by species (Table $3, P<0.0001$ ), and generally increased with light availability $\left(R^{2}=0.22\right.$; Table $\left.3, P<0.005\right)$, although these responses were highly variable. Because of the differential species responses in aboveground and belowground biomass, total biomass showed strong species differences (Table $3, P<0.0001$ ). P. strobus had the largest total biomass with $2.44 \pm 0.11 \mathrm{~g}$ per plant and $F$. grandifolia displayed the lowest total biomass at $0.71 \pm 0.13 \mathrm{~g}$. In general, total biomass increased with light availability across species $\left(R^{2}=0.26\right.$; Table 3 , $P<0.0001$ ). 
Table 3 Analysis of covariance (ANCOVA) of seedling biomass growth and survival for species grown in ambient and elevated $\left[\mathrm{CO}_{2}\right]$, understory shade, and with high and low $\mathrm{N}$ availability

\begin{tabular}{|c|c|c|c|c|c|c|c|c|c|c|c|c|c|c|c|}
\hline \multirow{2}{*}{$\begin{array}{l}\text { Sources of } \\
\text { variation }\end{array}$} & \multicolumn{3}{|c|}{$\begin{array}{l}\text { Aboveground } \\
\text { biomass growth }\end{array}$} & \multicolumn{3}{|c|}{$\begin{array}{l}\text { Belowground } \\
\text { biomass growth }\end{array}$} & \multicolumn{3}{|c|}{$\begin{array}{l}\text { Total biomass } \\
\text { growth }\end{array}$} & \multicolumn{3}{|c|}{ Height growth } & \multicolumn{3}{|c|}{ Survival } \\
\hline & $\mathrm{df}$ & $F$ & $P$ & $\mathrm{df}$ & $F$ & $P$ & $\mathrm{df}$ & $F$ & $P$ & $\mathrm{df}$ & $F$ & $P$ & $\mathrm{df}$ & $F$ & $\mathrm{P}$ \\
\hline $\mathrm{CO}_{2}$ & 1 & 0.8 & ns & 1 & 0.4 & ns & 1 & 1.0 & ns & 1 & 3.0 & 0.085 & 1 & 1.5 & ns \\
\hline Nitrogen & 1 & 3.6 & 0.060 & 1 & 1.0 & ns & 1 & $<0.01$ & ns & 1 & $<0.01$ & ns & 1 & 6.4 & 0.012 \\
\hline Species & 5 & 6.0 & $<0.0001$ & 5 & 5.3 & $<0.0001$ & 5 & 7.0 & $<0.0001$ & 5 & 12.0 & $<0.0001$ & 5 & 15.0 & $<0.0001$ \\
\hline Light & 1 & 12.6 & $<0.0001$ & 1 & 7.9 & 0.005 & 1 & 13.5 & $<0.0001$ & 1 & 0.9 & ns & 1 & 0.1 & ns \\
\hline $\mathrm{CO}_{2} \times$ nitrogen & 1 & 0.2 & ns & 1 & $<0.01$ & ns & 1 & 0.04 & ns & 1 & $<0.01$ & ns & 1 & 7.0 & 0.009 \\
\hline $\mathrm{CO}_{2} \times$ species & 5 & 0.6 & ns & 5 & 1.7 & ns & 5 & 1.5 & ns & 5 & 0.7 & ns & 5 & 1.8 & ns \\
\hline $\mathrm{CO}_{2} \times$ light & 1 & 0.1 & ns & 1 & 0.7 & ns & 1 & 0.8 & ns & 1 & 1.7 & ns & 1 & 0.8 & ns \\
\hline Nitrogen $\times$ species & 5 & 0.4 & ns & 5 & 0.6 & ns & 5 & 0.5 & ns & 5 & 1.1 & ns & 5 & 1.6 & ns \\
\hline Nitrogen $\times$ light & 1 & 3.8 & 0.051 & 1 & 0.1 & ns & 1 & 0.3 & ns & 1 & 0.3 & ns & 1 & 1.0 & ns \\
\hline Species $\times$ light & 5 & 5.9 & $<0.0001$ & 5 & 1.4 & ns & 5 & 0.4 & ns & 5 & 3.2 & 0.007 & 5 & 3.8 & 0.003 \\
\hline Initial plant height & 1 & 85.4 & $<0.0001$ & 1 & 18.3 & $<0.0001$ & 1 & 45.3 & $<0.0001$ & 1 & 67.9 & $<0.0001$ & & & \\
\hline Error & 300 & & & 297 & & & 297 & & & 298 & & & & & \\
\hline Total & 328 & & & 325 & & & 325 & & & 326 & & & & & \\
\hline $\begin{array}{l}\text { Random intercept } \\
\text { (chamber) }\end{array}$ & & & & & & & & & & & & & & & 0.016 \\
\hline
\end{tabular}

Aboveground, belowground, and total biomass results, as well as height growth results, are shown for the univariate ANCOVA model with initial plant height as a covariate. The linear-mixed ANCOvA model for seedling survival is also shown. The significance of the treatment effect on each parameter is indicated by the $P$-value (ns, nonsignificant, $P \geq 0.1$ ). Bold values indicates $P<0.05$.

\section{Survival}

Overall, increased $\mathrm{N}$ availability significantly improved rates of seedling survival in the understory (Table 3, $P<0.012)$, wherein plants that were grown with high $\mathrm{N}$ availability displayed $48 \%$ greater survival than those species growing with low $\mathrm{N}$ availability (Fig. 3). In elevated $\left[\mathrm{CO}_{2}\right]$, there was a significant $\mathrm{CO}_{2}$ by $\mathrm{N}$ interaction (Fig. 3; Table 3, $P<0.009$ ). At low $\mathrm{N}$-availability, seedlings grown in ambient and elevated $\left[\mathrm{CO}_{2}\right]$ showed similar survival rates $(57 \% \pm 5 \%$ and $55 \% \pm 4 \%$, respectively). However, for plants grown with high $\mathrm{N}$ availability, those grown in ambient $\left[\mathrm{CO}_{2}\right]$ demonstrated $78 \pm 4 \%$ survival, and those grown in elevated $\left[\mathrm{CO}_{2}\right]$ exhibited the greatest survival rate of all of the treatment combinations with an $85 \pm 2 \%$ survival rate.

There was no significant light by $\mathrm{N}$ interaction for survival, meaning that plants grown with high $\mathrm{N}$ availability did not survive better as light increased. Individual species, on the other hand, displayed survival rates that were dependent on light availability (Table 3, $P<0.003)$. Multiple comparisons tests show that survival rates did not change as light availability increased for A. saccharum, $P$. strobus, F. grandifolia, and $P$. serotina $(P>0.05$, data not shown in a table). Conversely, survival rates increased substantially for shade intolerant $B$. papyrifera $(P<0.009)$ and $P$. tremuloides $(P<0.002)$ as light availability increased.

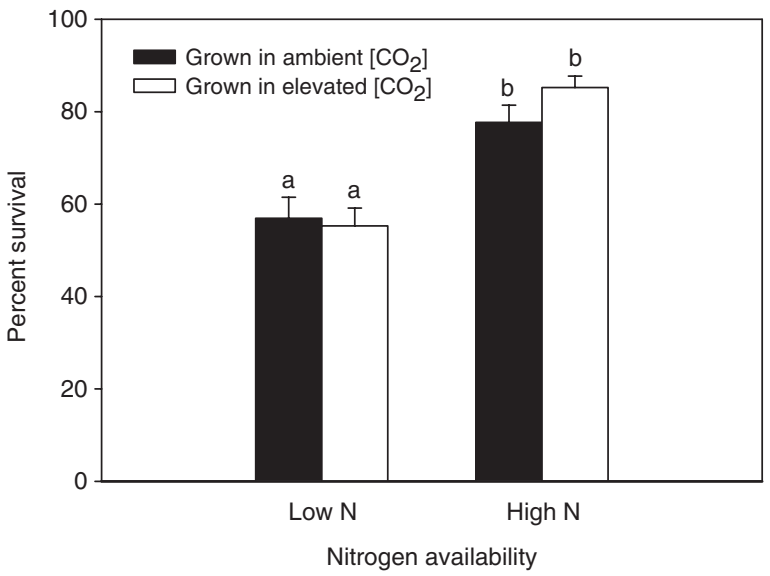

Fig. 3 Percent survival of plants grown in elevated or ambient $\left[\mathrm{CO}_{2}\right]$, and high and low $\mathrm{N}$ availability is shown. Black bars indicate plants grown in ambient $\left[\mathrm{CO}_{2}\right]$, and white bars represent plants grown in elevated $\left[\mathrm{CO}_{2}\right]$. Bonferroni multiple comparisons with $P<0.025$ (equivalent to experimental-wise $P<0.05)$ are shown. Distinct letters denote differences.

\section{Interactive effects - path analysis}

A path analysis was used to assess the effects of $\left[\mathrm{CO}_{2}\right]$, $\mathrm{N}$ availability, and light environment on $V_{\text {cmax }}$ and its subsequent effects on growth and seedling survival (Fig. 4). Although alternative interpretations of the path 


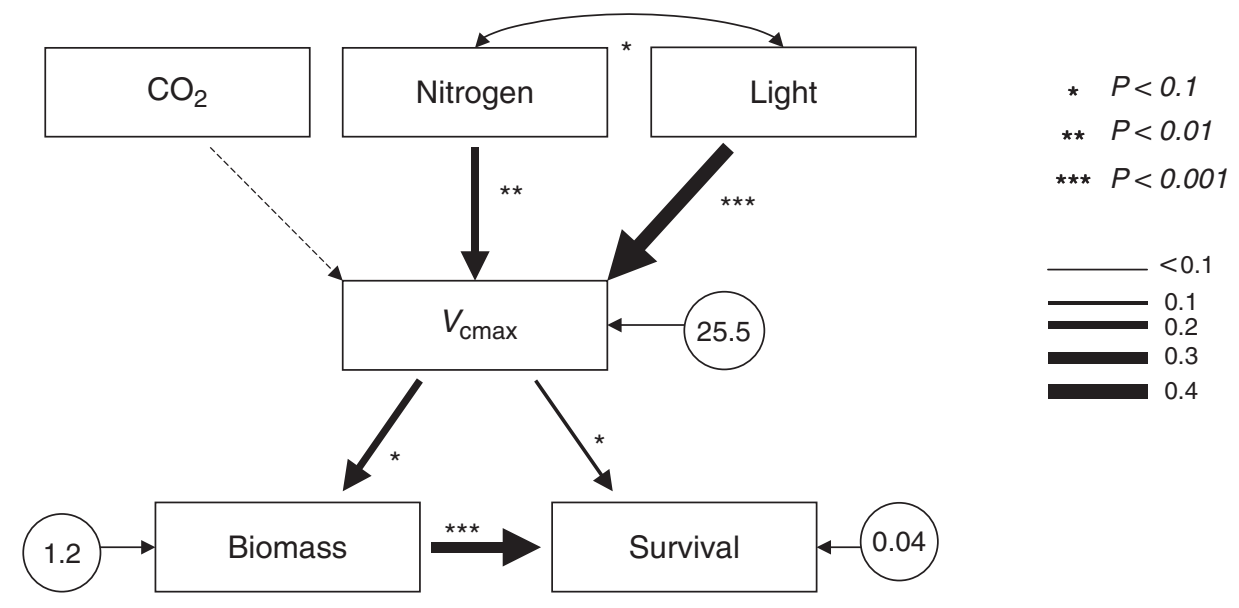

Standardized direct and indirect effects

\begin{tabular}{lccccc} 
& $\mathrm{CO}_{2}$ & Light & Nitrogen & $V_{\mathrm{cmax}}$ & Biomass \\
\hline$V_{\mathrm{cmax}}$ & -0.074 & 0.451 & 0.206 & - & - \\
\hline Biomass & -0.011 & 0.066 & 0.030 & 0.146 & - \\
\hline Survival & -0.015 & 0.094 & 0.043 & 0.208 & 0.386
\end{tabular}

Fig. 4 Solved path diagram showing the effects of growth light environment, $\left[\mathrm{CO}_{2}\right]$, and $\mathrm{N}$ availability on maximum carboxylation capacity $\left(V_{\text {cmax }}\right)$, total biomass and seedling survival. Solid lines denote positive effects, and dashed lines denote negative effects. Width of lines is proportional to the strength of the relationship, and paths significantly greater than zero are shown with an asterisk. Number of asterisks denotes strength of significance, with ${ }^{*}, P<0.1 ;{ }^{* *}, P<0.01 ; * * *, P<0.001$. Values associated with each path are standardized direct and indirect regression coefficients shown in the table. Circles denote random errors of estimation due to all other unmeasured causes.

interactions are possible (Grace \& Pugesek, 1998), our analysis determined that there was good agreement between the correlations observed in our data and the correlation that would theoretically occur if the path diagram were correct $(N=134, \mathrm{df}=8$, root mean square error of approximation (RMSEA) with $P$-value testing the null that RMSEA is no greater than $0.05, P>0.14$ ). This suggests that there is no significant deviation between observed and expected correlation matrices, signifying that it is possible that the causal structure of our path diagram could be the actual causal structure for the system (Mitchell, 2001).

Light environment had the largest total positive effect on $V_{\text {cmax }}$ (Fig. $4, R^{2}=0.45, P<0.001$ ). $\mathrm{N}$ also exhibited a significant positive effect on $V_{\text {cmax }}\left(R^{2}=0.21, P<0.006\right)$. Thus, as $\mathrm{N}$ and light increase, $V_{\mathrm{cmax}}$, or the amount of active Rubisco enzyme increases. On the other hand, $\left[\mathrm{CO}_{2}\right]$ had a nonsignificant effect on $V_{\text {cmax }}\left(R^{2}=-0.07\right.$, $P>0.1$. Maximum carboxylation capacity had a significant positive effect on total biomass (Fig. $4, R^{2}=0.15$, $P<0.09$ ), meaning that as $V_{\text {cmax }}$ increased, total biomass also increased. Moreover, $V_{\mathrm{cmax}}$ had a significant positive effect on the rate of seedling survival $\left(R^{2}=0.21\right.$, $P<0.055)$. These results suggest that as the amount of active Rubisco enzyme increases, plants will increase total biomass and rate of survival. Total biomass had the largest influence on the rate of survival with a significant positive effect (Fig. $4, R^{2}=0.39, P<0.001$ ). This suggests that an increase in plant size will have the largest positive impact on survival of these species in the understory.

In a second path analysis (figure not shown), we tested the effects of $\left[\mathrm{CO}_{2}\right], \mathrm{N}$, and light availability on $A_{\text {max }}$, and its subsequent effects on total biomass and seedling survival to determine what photosynthetic factors were most important to understory growth and survival. The path was structured in an identical manner as in Fig. 4 with $A_{\max }$ in the place of $V_{\text {cmax }}$. The analysis again showed that there was good agreement between the correlations observed in our data and the correlation that would theoretically occur if the path diagram were correct $(N=134, \mathrm{df}=8$, RMSEA $P>0.13)$. $\mathrm{CO}_{2}$ concentration had the largest positive effect on $A_{\max }\left(R^{2}=0.47, P<0.001\right)$. Light also exhibited a large significant positive effect on $A_{\max }\left(R^{2}=0.40, P<0.001\right)$. $\mathrm{N}$ had the lowest effect on $A_{\text {max }}$; however, the effect was still large, significant and positive $\left(R^{2}=0.28, P<0.001\right)$. Thus, for the northern hardwood species in this study, increases in $\left[\mathrm{CO}_{2}\right], \mathrm{N}$ and light availability produce large increases in $A_{\max }$. Interestingly, we found that 
changes in $A_{\max }$ did not significantly affect total biomass $\left(R^{2}=0.11, P>0.1\right)$ or rate of survival $\left(R^{2}=0.16\right.$, $P>0.1$ ). Again, total biomass had the largest influence on the rate of survival with a strong, significant positive effect $\left(R^{2}=0.39, P<0.001\right)$. These results suggest that $V_{\text {cmax }}$ as a proxy for the amount of active Rubisco enzyme, may give a better estimate of interactive treatment effects on growth and survival than $A_{\max }$.

\section{Discussion}

It has been suggested that if $\mathrm{N}$ deposition increases concurrently with atmospheric $\left[\mathrm{CO}_{2}\right]$, this may result in a greater physiological response to elevated $\mathrm{CO}_{2}$ because $\mathrm{N}$ deposition may alleviate $\mathrm{N}$-limitation experienced by many terrestrial forest ecosystems (Aber et al., 2003). Based on this idea, we hypothesized that greater $\mathrm{N}$ availability from experimental $\mathrm{N}$ deposition would increase leaf $N_{\text {area, }}$ photosynthesis, growth, and survival for understory seedlings in our N-limited northern Michigan study site, especially as light availability increased (Field \& Mooney, 1983; Peterson et al., 1999). Our results demonstrate that seedlings growing in high $\mathrm{N}$ availability had the greatest leaf $N_{\text {area }}$ and this generally increased with light availability. However, $N_{\text {area }}$ was also species-specific and depended on $\left[\mathrm{CO}_{2}\right]$; thus, it is difficult to make a generalization about trends for $N_{\text {area }}$ among species (Luo et al., 1994; Bauer et al., 2001).

\section{Photosynthesis}

We found that elevated $\mathrm{CO}_{2}$ exposure significantly increased light-limited and light-saturated photosynthesis, as well as apparent quantum efficiency of electron transport, when compared with seedlings grown in ambient $\left[\mathrm{CO}_{2}\right]$. These increases in photosynthetic parameters ranged between $41 \%$ and $60 \%$ and were similar to rates found in other studies (Curtis \& Wang, 1998; DeLucia \& Thomas, 2000). We expected that downregulation of photosynthesis would occur with elevated $\mathrm{CO}_{2}$ exposure due to $\mathrm{N}$-limitation in our $\mathrm{N}$ poor soil (Kubiske et al., 1997; Sefcik et al., 2006). Our results support this idea because we found seedlings grown in elevated $\mathrm{CO}_{2}$ and low $\mathrm{N}$ availability exhibited significant $11 \%$ downregulation of light-saturated photosynthetic capacity $(P<0.003)$ compared with ambient $\mathrm{CO}_{2}$ grown seedlings in the same $\mathrm{N}$ treatment (Fig. 1). We also reasoned that plants grown with high $\mathrm{N}$ availability would increase $V_{\text {cmax }}$ and light-saturated photosynthetic rate, alleviating the downregulation response for plants grown under elevated $\left[\mathrm{CO}_{2}\right]$ (Saxe et al., 1998; Medlyn et al., 1999). Our results partially support this contention because high $\mathrm{N}$ availability alleviated the downregulation of light-saturated net photosynthesis for species growing in elevated $\left[\mathrm{CO}_{2}\right]$ (Fig. 1 and Table 2). Interestingly, high $\mathrm{N}$ availability did not significantly affect $V_{\text {cmax }}$, which is contrary to our supposition that downregulation would be alleviated by $\mathrm{N}$ addition, mediated through $V_{\text {cmax }}$ or changes in the amount of Rubisco (Medlyn et al., 1999).

Our results support the contention that the effect of $\mathrm{N}$ on photosynthetic acclimation to elevated $\left[\mathrm{CO}_{2}\right]$ may depend on the availability of a growth sink for the extra carbohydrates produced under $\mathrm{CO}_{2}$ enrichment (Tissue et al., 2001; Jifon \& Wolfe, 2002; Crous \& Ellsworth, 2004). Studies have found that soil fertility can restrain the plant growth response to $\mathrm{CO}_{2}$ enrichment (Kubiske et al., 1997; Curtis et al., 2000; Oren et al., 2001; Tissue et al., 2001). Our results further suggest that soil $\mathrm{N}$ availability may mediate the acclimation response of photosynthesis to $\mathrm{CO}_{2}$ enrichment, with low $\mathrm{N}$ sites acclimating more to elevated $\mathrm{CO}_{2}$ than sites having higher fertility (Medlyn et al., 2000, Kubiske et al., 2002). This suggests that the response of ecosystems to enriched atmospheric $\left[\mathrm{CO}_{2}\right]$ will depend on the nutrient availability of the ecosystem (Saxe et al., 1998; Körner, 2000; McMurtrie et al., 2001; Spinnler et al., 2002). We observed that species light-saturated net photosynthesis was dependent on light and $\mathrm{N}$ availability in the understory (Table 1 and Fig. 2). This suggests that, for some species, increases in $\mathrm{N}$ availability via atmospheric deposition may be important for seedling photosynthesis and subsequent carbon gain in lightand N-limited, understory environments (Field \& Mooney, 1983).

\section{Growth}

Overall, our results determined that seedling growth differed significantly by species, and increased slightly with light availability (Walters \& Reich, 2000); although, the variability in these responses was large. Others have also found variation in the growth response among species (Bazzaz et al., 1990; Rochefort \& Bazzaz, 1992; Curtis \& Wang, 1998), potentially due to species specific life history traits related to plant carbon balance. In our study, biomass growth did not follow patterns related to shade tolerance groups as $P$. strobus a mid- to shadetolerant species exhibited the greatest total growth, and F. grandifolia, a shade tolerant species, had the smallest total growth. The rank order for total growth was $P$. strobus $>P$. tremuloidies $>A$. saccharum $>P$. serotina $>$ B. papyrifera $>F$. grandifolia, which shows no pattern with shade tolerance group rankings. Hättenschwiler (2001) also found that seedling biomass growth did not correlate well with shade tolerance group ranking, and concluded that functional group characteristics may not be sufficient for understanding 
forest recruitment dynamics as global atmospheric composition changes.

\section{Survival}

Species exhibited differential survival rates that were dependent on light availability (Table 3; Walters \& Reich, 2000) and were characteristic for shade tolerance group rankings. For example, survival rates did not change as light availability increased for more shade tolerant species A. saccharum and F. grandifolia, whereas survival rates increased significantly for shade intolerant B. papyrifera and P. tremuloides as light availability increased. This suggests that an increase in light availability from approximately $2 \%$ to $8 \%$ of full sun can have profound effects on the sustained survival of more shade intolerant species in the understory. Experimental $\mathrm{N}$ deposition increased overall seedling survival by $48 \%$, which is highly significant and biologically important for understanding understory recruitment dynamics as $\mathrm{N}$ deposition from fossil fuel combustion intensifies (Table 3 and Fig. 3; Walters \& Reich, 2000). We did not observe a significant interaction between $\mathrm{N}$ and light for survival, which was found in two other studies (Walters \& Reich, 2000; Catovsky \& Bazzaz, 2002). However, $\mathrm{N}$ deposition interacted with $\left[\mathrm{CO}_{2}\right]$, wherein seedlings grown in elevated $\left[\mathrm{CO}_{2}\right]$ and high $\mathrm{N}$ availability exhibited the greatest survival rates $(85 \%)$ of all treatment combinations (Rochefort \& Bazzaz, 1992). Our results suggest that increased $\mathrm{N}$ deposition may have considerable effects on understory seedling photosynthesis and rates of survival, especially in the presence of $\mathrm{CO}_{2}$-enrichment, which could alter the regeneration patterns and competitive ability in some species relative to others (Bazzaz et al., 1990; Rochefort \& Bazzaz, 1992). These changes in competitive ability might then modify forest species composition, subsequently altering successional patterns (Ceccon et al., 2004).

Integration of photosynthesis, growth, and survival results

We expected that the large increases evident in net photosynthesis from elevated $\mathrm{CO}_{2}$ exposure, high $\mathrm{N}$ availability, and high light availability, would confer increased growth for the northern hardwood species in our study. Our supposition was based on studies that have shown that photosynthesis can explain much of the variation in plant growth in moderate to high light (Poorter \& Remkes, 1990; Reich et al., 1992, 1998; Walters et al., 1993a). However, studies have also shown that there are discrepancies in this trend, especially in low light, which is more representative of our results (Poorter,
1989; Körner, 1991). Although Walters et al. (1993a), found a relationship with photosynthesis and growth in high light, they also determined that under lower light, growth was only correlated with allocation to leaves and not with photosynthetic rate. Kitajima (1994) also found that there was a positive correlation between photosynthesis and growth in $23 \%$ of full sun, but not in $2 \%$ of full sun. Hättenschwiler \& Körner (2000) also found that elevated $\left[\mathrm{CO}_{2}\right]$ did not increase biomass for some species in deep understory shade despite increases in photosynthesis. We found that our treatments, which resulted in significant changes in seedling photosynthesis, only had minor effects on growth. This may be a function of limited carbon gain in low growth light, and potentially high maintenance and biomass loss costs due to fine root turn over, allocation to mycorrhizal symbionts (Körner, 1991), as well as from a relatively short experiment length. Our results support the contention that these carbon costs may mask variation in predictions of growth that are based on leaf photosynthetic capacity (Körner, 1991), especially in low carbon gain environments such as a deeply shaded understory.

Our results also suggest that $A_{\max }$ may not be a useful predictor for growth and seedling survival in similar deeply shaded understory environments and that other factors, such as light-limited $A$, dark respiration rate, $V_{\text {cmax }}$ or leaf allocation, may be more responsible for the relationship between seedling physiology, growth, and survival in shade (Körner, 1991; Kitajima, 1994; Montgomery, 2004). Although the light-saturated photosynthetic rate is of primary importance to plant carbon gain and can theoretically explain some of the variation in plant growth, in isolation, it seems to be far removed from the ecological success of a species (Beaudet et al., 2000). On the other hand, $V_{\text {cmax }}$ as a proxy for the amount of active Rubisco enzyme, gives a slightly better estimate of interactive treatment effects of $\left[\mathrm{CO}_{2}\right], \mathrm{N}$ and light on growth and survival than $A_{\text {max }}$. Because $V_{\text {cmax }}$ is independent of stomatal conductance, and because it is derived across a range of $\mathrm{CO}_{2}$ concentrations, whereas $A_{\max }$ is sensitive to random variation in conductance that can occur due to differences in water status among plants, differences in time of day, which affects stomatal opening, as well as many other factors, $V_{\text {cmax }}$ is more robust measurement than $A_{\max }$. This may explain why $V_{\text {cmax }}$ shows significance in some cases where $A_{\max }$ does not. Our results show that increases in light and $\mathrm{N}$ availability produced large positive effects on $V_{\text {cmax }}$, which in turn produced changes in growth and survival (Fig. 4; Manter et al., 2005). These results suggest that as the amount of active Rubisco enzyme increases, plants will also increase growth and survival. Yet, survival in the understory was influenced the 
greatest by plant biomass (Walters \& Reich, 1996), suggesting that an increase in plant size will have the largest single positive impact on survival for these species in the understory.

\section{Conclusions}

Anthropogenic changes in atmospheric composition, such as increasing $\left[\mathrm{CO}_{2}\right]$ and reactive $\mathrm{N}$ compounds, may impact biotic systems through changes in plant resource availability (Field et al., 1992). Our results demonstrate that current and future rates of $\mathrm{N}$ deposition as found or expected in the northeastern United States and Europe, can significantly impact the physiology and survival responses of understory seedlings in N-limited forest ecosystems. Our results show that increased $\mathrm{N}$ availability from deposition improved seedling survival by $48 \%$, and $\mathrm{CO}_{2}$ enrichment enhanced understory photosynthesis by $41-60 \%$. Our findings also suggest that $\mathrm{N}$ deposition may alleviate some photosynthetic acclimation to long-term $\mathrm{CO}_{2}$ enrichment in N-limited understory seedlings by increasing soil $\mathrm{N}$ availability. We conclude that elevated $\left[\mathrm{CO}_{2}\right]$ and $\mathrm{N}$ deposition may have interactive effects for $\mathrm{N}$ limited seedlings in understory environments, as seedlings had the greatest rates of survival (85\%) under elevated $\left[\mathrm{CO}_{2}\right]$ and high $\mathrm{N}$ availability. In summary, increasing $\left[\mathrm{CO}_{2}\right]$ and $\mathrm{N}$ deposition from fossil fuel combustion can directly impact seedling physiology and survivorship. Given that differential seedling survival largely determines forest composition through recruitment, changes in atmospheric composition have the potential to alter the regeneration patterns and species composition of $\mathrm{N}$-limited northern hardwood forests in a future higher $\mathrm{CO}_{2}$ and $\mathrm{N}$ world.

\section{Acknowledgements}

The Biosphere Atmosphere Research and Training (BART) Program, an Integrative Graduate Education and Research Traineeship (IGERT) Program through the National Science Foundation funded this research. We thank the University of Michigan Biological Station, Rackham Graduate School, and the School of Natural Resources and Environment at the University of Michigan for support. We also thank Brady West at the Center for Statistical Consultation and Research at the University of Michigan for guidance with statistical analyses.

\section{References}

Aber JD, Goodale CL, Ollinger SV et al. (2003) Is nitrogen deposition altering the nitrogen status of northeastern forests? Bioscience, 53, 375-389.

Aber JD, Nadelhoffer KJ, Steudler P et al. (1989) Nitrogen saturation in northern forest ecosystems. Bioscience, 39, 378386.
Aber J, Neilson RP, McNulty S et al. (2001) Forest processes and global environmental change: predicting the effects of individual and multiple stressors. Bioscience, 51, 735-751.

Baker FS (1949) A revised tolerance table. Journal of Forestry, 47, 179-181.

Baraloto C, Forget PM, Goldberg DE (2005) Seed mass, seedling size and neotropical tree seedling establishment. Journal of Ecology, 93, 1156-1166.

Bauer GA, Berntson GM, Bazzaz FA (2001) Regenerating temperate forests under elevated $\mathrm{CO}_{2}$ and nitrogen deposition: comparing biochemical and stomatal limitation of photosynthesis. New Phytologist, 152, 249-266.

Bazzaz FA, Coleman JS, Morse SR (1990) Growth response of seven major co-occurring tree species of the northeastern United States to elevated $\mathrm{CO}_{2}$. Canadian Journal of Forest Research-Revue Canadienne De Recherche Forestiere, 20, 1479-1484.

Bazzaz FA, Fajer ED (1992) Plant life in a $\mathrm{CO}_{2}$-rich world. Scientific American, 266, 68-74.

Bazzaz FA, Miao SL (1993) Successional status, seed size, and responses of tree seedlings to $\mathrm{CO}_{2}$, light, and nutrients. Ecology, 74, 104-112.

Beaudet M, Messier C, Hilbert DW et al. (2000) Leaf- and plantlevel carbon gain in yellow birch, sugar maple, and beech seedlings from contrasting forest light environments. Canadian Journal of Forest Research-Revue Canadienne De Recherche Forestiere, 30, 390-404.

Bondada BR, Syvertsen JP (2003) Leaf chlorophyll, net gas exchange and chloroplast ultrastructure in citrus leaves of different nitrogen status. Tree Physiology, 23, 553-559.

Catovsky S, Bazzaz FA (2002) Nitrogen availability influences regeneration of temperate tree species in the understory seedling bank. Ecological Applications, 12, 1056-1070.

Ceccon E, Sanchez S, Campo J (2004) Tree seedling dynamics in two abandoned tropical dry forests of differing successional status in Yucatan, Mexico: a field experiment with $\mathrm{N}$ and $\mathrm{P}$ fertilization. Plant Ecology, 170, 277-285.

Crous KY, Ellsworth DS (2004) Canopy position affects photosynthetic adjustments to long-term elevated $\mathrm{CO}_{2}$ concentration (FACE) in aging needles in a mature Pinus taeda forest. Tree Physiology, 24, 961-970.

Curtis PS, Vogel CS, Wang XZ et al. (2000) Gas exchange, leaf nitrogen, and growth efficiency of Populus tremuloides in a $\mathrm{CO}_{2}$-enriched atmosphere. Ecological Applications, 10, 3-17.

Curtis PS, Wang XZ (1998) A meta-analysis of elevated $\mathrm{CO}_{2}$ effects on woody plant mass, form, and physiology. Oecologia, 113, 299-313.

DeLucia EH, Thomas RB (2000) Photosynthetic responses to $\mathrm{CO}_{2}$ enrichment of four hardwood species in a forest understory. Oecologia, 122, 11-19.

Ellsworth DS, Reich PB, Naumburg ES et al. (2004) A comparison of photosynthetic characteristics and leaf nitrogen responses of 16 species to atmospheric $\mathrm{CO}_{2}$ across four free-air $\mathrm{CO}_{2}$ enrichment (FACE) experiments. Global Change Biology, 10, 2121-2138.

Farquhar GD, von Caemmerer S, Berry JA (1980) A biochemical model of photosynthetic $\mathrm{CO}_{2}$ assimilation in leaves of $\mathrm{C}_{3}$ species. Planta, 149, 78-90. 
Field CB, Chapin FS, Matson PA III. et al. (1992) Responses of terrestrial ecosystems to the changing atmosphere: a resourcebased approach. Annual Review of Ecosystem and Systematics, 23, 201-235.

Field C, Mooney HA (1983) The photosynthesis - nitrogen relationship in wild plants. In: On the Economy of Plant Form and Function (ed. Givnish TJ), pp. 25-53. Cambridge University Press, Cambridge.

Galloway JN, Aber JD, Erisman JW et al. (2003) The nitrogen cascade. Bioscience, 53, 341-356.

Grace JB, Pugesek BH (1998) On the use of path analysis and related procedures for the investigation of ecological problems. American Naturalist, 152, 151-159.

Greenep H, Turnbull MH, Whitehead D (2003) Response of photosynthesis in second-generation Pinus radiata trees to long-term exposure to elevated carbon dioxide partial pressure. Tree Physiology, 23, 569-576.

Gueorguieva R, Krystal JH (2004) Move over ANOVA. Progress in analyzing repeated-measures data and its reflection in papers published in the Archives of General Psychiatry. Archives of General Psychiatry, 61, 310-317.

Hättenschwiler S (2001) Tree seedling growth in natural deep shade: functional traits related to interspecific variation in response to elevated $\mathrm{CO}_{2}$. Oecologia, 129, 31-42.

Hättenschwiler S, Körner C (2000) Tree seedling responses to in situ $\mathrm{CO}_{2}$-enrichment differ among species and depend on understory light availability. Global Change Biology, 6, 213-226.

Hättenschwiler S, Miglietta F, Raschi A et al. (1997) Thirty years of in situ tree growth under elevated $\mathrm{CO}_{2}$ : a model for future forest responses? Global Change Biology, 3, 463-471.

Hanson PJ, McRoberts RE, Isebrands JG et al. (1987) An optimal sampling strategy for determining $\mathrm{CO}_{2}$ exchange-rate as a function of photosynthetic photon flux-density. Photosynthetica, 21, 90-101.

Hungate BA, Dukes JS, Shaw MR et al. (2003) Nitrogen and climate change. Science, 302, 1512-1513.

IPCC (2001) Climate change 2001: the scientific basis. Contribution of working group I to the third assessment report of the Intergovernmental Panel on climate change. (eds Houghton JT, Ding Y, Griggs DJ, Noguer M, van der Linden PJ, Dai X, Maskell K, Johnson CA), Cambridge University Press, Cambridge, UK.

Jifon JL, Wolfe DW (2002) Photosynthetic acclimation to elevated $\mathrm{CO}_{2}$ in Phaseolus vulgaris L. is altered by growth response to nitrogen supply. Global Change Biology, 8, 1018-1027.

Körner C (1991) Some often overlooked plant characteristics as determinants of plant growth: a reconsideration. Functional Ecology, 5, 162-173.

Körner C (2000) Biosphere responses to $\mathrm{CO}_{2}$ enrichment. Ecological Applications, 10, 1590-1619.

Kerstiens G (2001) Meta-analysis of the interaction between shade-tolerance, light environment and growth response of woody species to elevated $\mathrm{CO}_{2}$. Acta Oecologica-International Journal of Ecology, 22, 61-69.

Kitajima K (1994) Relative importance of photosynthetic traits and allocation patterns as correlates of seedling shade tolerance of 13 tropical trees. Oecologia, 98, 419-428.
Kubiske ME, Pregitzer KS, Mikan CJ et al. (1997) Populus tremuloides photosynthesis and crown architecture in response to elevated $\mathrm{CO}_{2}$ and soil $\mathrm{N}$ availability. Oecologia, 110, 328-336.

Kubiske ME, Zak DR, Pregitzer KS et al. (2002) Photosynthetic acclimation of overstory Populus tremuloides and understory Acer saccharum to elevated atmospheric $\mathrm{CO}_{2}$ concentration: interactions with shade and soil nitrogen. Tree Physiology, 22, 321-329.

Kutik J, Lubomir N, Demmers-Derks HH et al. (1995) Chloroplast ultrastructure of sugar beet (Beta vulgaris L.) cultivated in normal and elevated $\mathrm{CO}_{2}$ concentrations with two contrasted nitrogen supplies. Journal of Experimental Botany, 46, 1797-1802.

Laitinen K, Luomala EM, Kellomaki S et al. (2000) Carbon assimilation and nitrogen in needles of fertilized and unfertilized field-grown Scots pine at natural and elevated concentrations of $\mathrm{CO}_{2}$. Tree Physiology, 20, 881-892.

Latham RE (1992) Co-occurring tree species change rank in seedling performance with resources varied experimentally. Ecology, 73, 2129-2144.

Lovett GM, Lindberg SE (1986) Dry deposition of nitrate to a deciduous forest. Biogeochemistry, 2, 137-148.

Lovett GM, Lindberg SE (1993) Atmospheric deposition and canopy interactions of nitrogen in forests. Canadian Journal of Forest Research-Reoue Canadienne De Recherche Forestiere, 23, 1603-1616.

Luo Y, Field CB, Mooney HA (1994) Predicting responses of photosynthesis and root fraction to elevated $\left[\mathrm{CO}_{2}\right]$ (A) interactions among carbon, nitrogen and growth. Plant, Cell and Environment, 17, 1195-1204.

Magill AH, Aber JD, Currie WS et al. (2004) Ecosystem response to 15 years of chronic nitrogen additions at the Harvard Forest LTER, Massachusetts, USA. Forest Ecology and Management, 196, 7-28.

Manter DK, Kavanagh KL, Rose CL (2005) Growth response of Douglas-fir seedlings to nitrogen fertilization: importance of Rubisco activation state and respiration rates. Tree Physiology, 25, 1015-1021.

McMurtrie RE, Medlyn BE, Dewar RC (2001) Increased understanding of nutrient immobilization in soil organic matter is critical for predicting the carbon sink strength of forest ecosystems over the next 100 years. Tree Physiology, 21, 831-839.

Medlyn BE, Badeck FW, De Pury DGG et al. (1999) Effects of elevated $\mathrm{CO}_{2}$ on photosynthesis in European forest species: a meta-analysis of model parameters. Plant, Cell and Environment, 22, 1475-1495.

Medlyn BE, McMurtrie RE, Dewar RC et al. (2000) Soil processes dominate the long-term response of forest net primary productivity to increased temperature and atmospheric $\mathrm{CO}_{2}$ concentration. Canadian Journal of Forest Research-Revue Canadienne De Recherche Forestiere, 30, 873-888.

Mikan CJ, Zak DR, Kubiske ME et al. (2000) Combined effects of atmospheric $\mathrm{CO}_{2}$ and $\mathrm{N}$ availability on the belowground carbon and nitrogen dynamics of aspen mesocosms. Oecologia, 124, 432-445.

Mitchell RJ (2001) Path Analysis: pollination. In: Design and Analysis of Ecological Experiments (eds Scheiner SM, Gurevitch J), pp. 217-234. Oxford University Press Inc., New York City. 
Montgomery R (2004) Relative importance of photosynthetic physiology and biomass allocation for tree seedling growth across a broad light gradient. Tree Physiology, 24, 155-167.

Naumburg E, Ellsworth DS (2000) Photosynthesis sunfleck utilization potential of understory saplings growing under elevated $\mathrm{CO}_{2}$ in FACE. Oecologia, 122, 163-174.

Oren R, Ellsworth DS, Johnsen KH et al. (2001) Soil fertility limits carbon sequestration by forest ecosystems in a $\mathrm{CO}_{2}$-enriched atmosphere. Nature, 411, 469-472.

Parent S, Messier C (1996) A simple and efficient method to estimate microsite light availability under a forest canopy. Canadian Journal of Forest Research-Revue Canadienne De Recherche Forestiere, 26, 151-154.

Peterson AG, Ball JT, Luo YQ et al. (1999) The photosynthesis leaf nitrogen relationship at ambient and elevated atmospheric carbon dioxide: a meta-analysis. Global Change Biology, 5, 331-346.

Poorter H (1989) Interspecific variation in relative growth rate: on ecological causes and physiological consequences. In: Causes and Consequences of Variation in Growth Rate and Productivity of Higher Plants (eds Lambers H, Cambridge ML, Konings H, Pons TL), pp. 45-68. SPB Academic Publishing, The Hague.

Poorter H, Remkes C (1990) Leaf area ratio and net assimilation rate of 24 wild species differing in relative growth rate. Oecologia, 83, 553-559.

Pregitzer KS, Zak DR, Burton AJ et al. (2004) Chronic nitrate additions dramatically increase the export of carbon and nitrogen from northern hardwood ecosystems. Biogeochemistry, 68, 179-197.

Reich PB, Tjoelker MG, Machado JL et al. (2006) Universal scaling of respiratory metabolism, size and nitrogen in plants. Nature, 439, 457-461.

Reich PB, Walters MB, Ellsworth DS (1992) Leaf life-span in relation to leaf, plant, and stand characteristics among diverse ecosystems. Ecological Monographs, 62, 365-392.

Reich PB, Walters MB, Tjoelker MG et al. (1998) Photosynthesis and respiration rates depend on leaf and root morphology and nitrogen concentration in nine boreal tree species differing in relative growth rate. Functional Ecology, 12, 395-405.

Rey A, Jarvis PG (1998) Long-term photosynthetic acclimation to increased atmospheric $\mathrm{CO}_{2}$ concentration in young birch (Betula pendula) trees. Tree Physiology, 18, 441-450.

Rochefort L, Bazzaz FA (1992) Growth response to elevated $\mathrm{CO}_{2}$ in seedlings of four co-occurring birch species. Canadian Journal of Forest Research-Revue Canadienne De Recherche Forestiere, 22, 1583-1587.

Rossell C, Gorsira B, Patch S (2005) Effects of white-tailed deer on vegetation structure and woody seedling composition in three forest types on the Piedmont Plateau. Forest Ecology and Management, 210, 415-424.

Saxe H, Ellsworth DS, Heath J (1998) Tree and forest functioning in an enriched $\mathrm{CO}_{2}$ atmosphere. Tansley Review No. 98. New Phytologist, 139, 395-436.

Sefcik LT, Zak DR, Ellsworth DS (2006) Photosynthetic responses to understory shade and elevated $\mathrm{CO}_{2}$ in four northern hardwood tree species. Tree Physiology, 26, 1589-1599.

Sholtis JD, Gunderson CA, Norby RJ et al. (2004) Persistent stimulation of photosynthesis by elevated $\mathrm{CO}_{2}$ in a sweetgum (Liquidambar styraciflua) forest stand. New Phytologist, 162, 343-354.

Singsaas EL, Ort DR, DeLucia EH (2001) Variation in measured values of photosynthetic quantum yield in ecophysiological studies. Oecologia, 128, 15-23.

Spinnler D, Egh P, Körner C (2002) Four-year growth dynamics of beech-spruce model ecosystems under $\mathrm{CO}_{2}$ enrichment on two different forest soils. Trees-Structure and Function, 16, 423-436.

Sterck F, Bongers F (2001) Crown development in tropical rain forest trees: patterns with tree height and light availability. Journal of Ecology, 89, 1-13.

Tissue DT, Griffin KL, Turnbull MH et al. (2001) Canopy position and needle age affect photosynthetic response in field-grown Pinus radiata after five years of exposure to elevated carbon dioxide partial pressure. Tree Physiology, 21, 915-923.

Vitousek PM, Mooney HA, Lubchenco J et al. (1997) Human domination of earth's ecosystems. Science, 277, 494-499.

Walters MB, Kruger EL, Reich PB (1993a) Relative growth-rate in relation to physiological and morphological traits for northern hardwood tree seedlings - species, light environment and ontogenetic considerations. Oecologia, 96, 219-231.

Walters MB, Kruger EL, Reich PB (1993b) Growth, biomass distribution and $\mathrm{CO}_{2}$ exchange of northern hardwood seedlings in high and low light - relationships with successional status and shade tolerance. Oecologia, 94, 7-16.

Walters MB, Reich PB (1996) Are shade tolerance, survival, and growth linked? Low light and, nitrogen effects on hardwood seedlings. Ecology, 77, 841-853.

Walters MB, Reich PB (2000) Seed size, nitrogen supply, and growth rate affect tree seedling survival in deep shade. Ecology, 81, 1887-1901.

Wolfe DW, Gifford RM, Hilbert D et al. (1998) Integration of photosynthetic acclimation to $\mathrm{CO}_{2}$ at the whole-plant level. Global Change Biology, 4, 879-893.

Zak DR, Grigal DF, Ohmann LF (1993) Kinetics of microbial respiration and nitrogen mineralization in Great-Lakes forests. Soil Science Society of America Journal, 57, 1100-1106. 